\title{
Interfaces
}

INTERFACES Image Texte Language

$40 \mid 2018$

Gestures and Transmission

\section{Donald Friedman's Interviews : Writers as Visual Artists}

\section{Maurice Géracht}

\section{(2) OpenEdition}

1 Journals

Electronic version

URL: http://journals.openedition.org/interfaces/612

DOI: 10.4000/interfaces.612

ISSN: 2647-6754

\section{Publisher:}

Université de Bourgogne, Université de Paris, College of the Holy Cross

\section{Printed version}

Date of publication: 21 December 2018

Number of pages: 209-213

ISSN: 1164-6225

\section{Electronic reference}

Maurice Géracht, "Donald Friedman's Interviews : Writers as Visual Artists", Interfaces [Online], 40 |

2018, Online since 21 December 2018, connection on 07 January 2021. URL: http://

journals.openedition.org/interfaces/612 ; DOI: https://doi.org/10.4000/interfaces.612

\section{(c) (1)}

Les contenus de la revue Interfaces sont mis à disposition selon les termes de la Licence Creative Commons Attribution 4.0 International. 


\title{
DONALD FRIEDMAN'S INTERVIEWS: WRITERS AS VISUAL ARTISTS
}

\author{
Maurice Géracht \\ College of the Holy Cross
}

With Volume 39, "Gestures and their Traces" INTERFACES, now an on-line journal,began its third iteration. ${ }^{1}$ In volume 40, we welcome Donald Friedman, novelist, essayist, and preeminently the author of The Writer's Brush, Paintings, Drawings, and Sculpture by Writers, as a regular contributor to the journal. In the process of researching The Writer's Brush, he video interviewed a number of contemporary writers; he is editing these tapes and these will begin a new feature of the journal. The first video interview is that of Derek Walcott. The interview of Tom Wolfe or that of Kurt Vonnegut will appear in Volume 41. Lawrence Ferlinghetti and others will follow.

In his "Apologia, Acknowledgements, and Alternative Reading Paths," Don recounts his effort to bring The Writer's Brush to fruition, how he came to organize material he had collected over four decades, the people who were especially helpful, the institutions that gave him access to their archives and collections, and he extends his gratitude to friends and colleagues. While its form follows academic conventions, Don is not an academic, and without a university sponsor or publisher,

INTERFACES, Volumes 1 through 16 (1991-1999) published at the University of Bourgogne and conceived by Michel Baridon, its founding editor, appeared in the standard $8^{1 / 4}$ " $\mathrm{x} 5^{3 / 8}$ "format. The number of Illustrations were limited, often small, and rarely in color. The Journal earned the imprimatur of the CRNS in 1995. When Michel Baridon retired from the University of Bourgogne in 2000, editorial responsibility fell to Frederick Ogée, University of Paris-Diderot, and Maurice Géracht, College of the Holy Cross, Worcester; henceforth INTERFACES was published at the College of the Holy Cross. In 2003, the format and design changed with Volumes 21/22 "Architecture Against Death / Architecture contre la mort" which focused on the avant-garde work of partners, visual artist Shusaka Arakawa, and poet Madeline Gins. The volumes were now square, $7^{3 / 8} \times 7^{3 / 8}$; Volume 21 includes a CD which contains 124 color images, and Volume 22 is accompanied by an Arakawa/Gins signed and numbered colored architectural print of the Biocleave House / Gallmann Residence they designed, and is now build in East Hampton, Long Island, N.Y. Ensuing issues followed these models, including an appropriate original signed and numbered art work. It won CELJ's Parnassus Award in 2010.In 2011, an agreement between the College of the Holy Cross, the University of Paris-Diderot, and the University of Bourgogne in Dijon tripled its institutional subsidy, and enlarged its editorial staff. Newly invigorated, full colored illustrations were incorporated in the text; the CD was reserved for moving images. With Volume 39 and its third iteration as an e-journal, INTERFACES will include video interviews, and will welcome appropriate video art. 
he regularly encountered gatekeepers who initially blocked access to archives and collections. How he gained access to the Berg Collection at the New York Public Library, and to the Newberry in Chicago which had the only remaining copy of the catalog of $A$ Second Talent: An Exhibition of Drawings and Paintings by Writers exhibited at the Chicago Art Club, have now become amusing anecdotes. Exchanging Hats the first exhibit of Elizabeth Bishop's painting, also an early research source, had been expanded into a book. ${ }^{2}$ The story of Friedman's remarkable research achievement is yet to be told, and it is for Don to fully tell it. A small part of that research narrative is shown in the video interviews he made; how some of these came about he shared with me in a telephone conversation on Tuesday morning, September 8, 2018.

Not only did he interview over two dozen writers who also create visual arts, many are well known names - John Berger, Tom Wolfe, Lawrence Ferlinghetti, Derek Walcott, Amiri Baraka, others, if somewhat less trumpeted, are of equal interest and importance. ${ }^{3}$ More importantly, the process of discovery continues. He has just created a gallery on his website for the artwork of writers - both established and new-who are not among the 200-plus subjects of The Writer's Brush. Presently at https://donaldfriedman.com/gallery/ you will find art by Joseph Brodsky, Jorge Luis Borges, Ken Kesey, Annie Proulx and others, along with the stories behind the art. More images and related text are being posted every few weeks. Additional on-camera interviews with writer-artists are also planned and will appear in INTERFACES.

In his preparation for the interviews Friedman read as much as he could about the writers as well as what they had published with the goal of posing questions that would engage and illuminate. At the same time, he says, he tried never to forget that they were the talent and he merely the audience. Accordingly, he happily allowed the writers to enlarge or change the direction of the conversation, content to record their words, their body language, their environment. And that is what makes these videos so particularly telling.

Perhaps reminiscent of some of W.M. Thackeray's ironic pen capital drawings in Vanity Fair, Vonnegut first introduced his graphics in order to comment on his text in Breakfast of Cham-

William Benton curated Exchanging Hats, an exhibit of 27 artworks by Elizabeth Bishop in January 1993 at the East Martello Tower Museum as part of the Key West Literary Seminar on Bishop's writing. Benton later published Exchanging Hats: Paintings. (New York: Farrar, Straus and Giroux, 1996). It reproduced in full forty of her water colors and cites painterly passages from Bishop's writing.

3 The list includes: Ralph Steadman, Jules Feiffer, Peter Sacks, Charles Johnson, Mark Strand, Richard Wilbur, Charles Simic, Debora Greger, Donald Finkel, Donald Justice, Guy Davenport, Susan Minot, Jonathan Lethem, Evan Hunter, Hugh Nissenson, Michael McClure, Janwillem Vanderwetering, Russell Edson, and Breyten Breytenbach. 
pions (1973). Prolific and masterful, his artworks were appreciated at several gallery exhibitions. ${ }^{4}$ In The fall of 2000, while Vonnegut taught at Smith in Northampton, Massachusetts, he had a show of his drawings, paintings, sculptures, and prints, which he collectively called "new cubism." It was there in the R. Michelson Gallery that Friedman recorded the interview. He had brought with him a professional documentary film maker, and the Gallery's proprietor hoped the film would benefit both the show and the Gallery,

Friedman scheduled the interview for the early part of the morning when Vonnegut would be "at his best." Clearly Vonnegut is having a good time talking about the process of creating visual art; he claims there is for him less constraint drawing a line, than forming a line of words: he says he can use two hands, it is physical, like dancing! And we do see him dancing as he talks. For the most part, the artworks are self-portraits: at once whimsical, humorous, satirical, poignant, ironic, objective, self-reflective, and self-deprecating.

Interestingly, Vonnegut's sense of the liberation and satisfaction the practice of the visual art can afford to everyone - as opposed to the strains and disappointments the written word extorts - is shared by writers as different as Tom Wolfe whose graphics are wicked satires of our social mores, and Derek Walcott whose realistic watercolors and paintings sympathetically depict the everyday life and color of St. Lucia, his Caribbean Island.

Wolfe drew from childhood onward, and mostly self-taught, he learned anatomy by studying photos of boxers in magazines, and from a late $19^{\text {th }}$ - to mid- $20^{\text {th }}$ century German satiric magazine ${ }^{5}$ illustrated by classically trained artists. He is particularly observant of how well the hand is represented. Whereas Wolfe claims that criticism of his writing, for which he is perhaps better known, does not disturb him, aspersions of his drawings do. Wolfe asserts that drawing and writing have nothing to do with each other; still there is in both his words and his images the same sensibility - a scathing wit in the exact words and phrases, precision and particularity of expression in the hands and facial features of his caricatures.

Derek Walcott tells Friedman that light was at the root of all art. Walcott mentions Vermeer, but insists that the light in his paintings is not merely derived from keen observation and a masterful brush, but comes from within Vermeer himself. Likewise, the warmth and light that glow in Walcott's

$4 \quad$ Friedman cites a solo show at New York's Margo Fiden Gallery in 1983 and at the Elaine Benson Gallery, Bridgehampton, New York in 2000.

5 Deriving its title from the $17^{\text {th }}$-century German picaresque novel of the same name, Simplicissmus was a satirical German weekly magazine started in 1896. Its best years were pre-WWI and during the Weimar Republic. Its most reliable targets for caricature were Prussian military figures, and rigid German social and class distinctions. 
watercolors, evident even in the reproductions, express his sensibility; it is a sensibility of the eye and voice at once personal and universal. He writes of his experiences, but not of his experiences only. He largely paints the locales close to his house in St. Lucia (N.B. Lucia, from Latin lux means light). But if some of his landscapes recall Pissarro's - at least a thematic affinity for things and people as they are - there is in his poetry also an empathy for the painter's experiences as a Sephardic Jew on St. Thomas (see "Tiepolo Hound"); the nineteenth century painter's fragmented Caribbean and Jewish identity was as familiar, as close to him, as his own.

Poet, painter, publisher, playwright, novelist, bookseller, scholar, critic, translator, Lawrence Ferlinghetti is most often remembered as a founding member of "the Beat" literary movement, and celebrated as a lifelong social activist. No sooner had he agreed to the interview than he declared that Friedman should not bring up the subject of his painting - the very point of the interview. Ferlinghetti insisted that painting and poetry have nothing to do with each other, that visual should not be approached or understood through words. Undaunted, Friedman prepared by digging out every Ferlinghetti poem that referred to painting and art. Ferlinghetti was willing to read the poems on camera but was obdurate about having any discussions about his painting, specifically, or even about painting in general. In retrospect, Ferlinghetti's reticence is not surprising. He strived for his poems and paintings to be broadly accessible; they are not meant to hold secrets for the few cognoscenti. His is a populist approach to the arts, and he is wary of cultural ambassadors and gatekeepers. It is a sensibility shared by the author of The Writer's Brush. In a wonderful fortuity, Ferlinghetti's gallerist mentioned that during WWII Ferlinghetti had served on a submarine chaser. Although Friedman was far too young to have served in the war, back in college he had found work one summer crewing on a converted WWII submarine chaser. When it turned out to be the same model ship on which Ferlinghetti served, there was an instantaneous bond--what Conrad called "the bond of the sea." Immediately Don was welcomed to his studio, instructed to turn on the camera as Ferlinghetti pulled down canvases and held forth. Ferlinghetti showed the same generosity in showing, sharing and talking about his work that he extended to the rock band Propagandhi when he gave the band permission to use his Unfinished Flag of the United States. Ever the egalitarian and activist, that image also appears as the cover of the band's 2001 release Today's Empire, Tomorrow's Ashes, and on the cover of Michael Parenti's Against Empire Ferlinghetti published via City Lights in 1995. Unfinished Flag, the stars and stripes painted overa map of the world, is also the major painting Ferlinghetti shared with Friedman for the full-page illustration of The Writer's Brush; significantly,ever the pertinent activist and egalitarian, the poet and painter also gave Don's word and image project The Woman Who Wouldn't Lie Down.

Each interview underscores the individuality of the writer/artist as creator and person. That is perhaps expected. Henry James in the "Preface to The Portrait of a Lady" reminds us that 
The house of fiction has in short not one window, but a million - a number of possible windows not to be reckoned, rather; every one of which has been pierced, or is still pierceable, in its vast front, by the need of the individual vision and by the pressure of the individual will.

What is unexpected and delightful is how Donald Friedman's video interviews particularly capture the "individual vision" of the writers/artists he encountered. INTERFACES thanks Donald Friedman for sharing and contributing his work.

\section{Works Cited}

A Second Talent: An Exhibition of Drawings and Paintings by Writers, Catalogue of the exhibition held in 1971 in Chicago Arts Club. Rue Winterbotham Shaw/publisher unknown.

ABSE, Dannie and Joan. Voices in the Gallery: Poems \& Pictures Chosen by Danie \& Joan Abse. Millbank, London: The Tate Gallery, 1986.

BENTON, William, and BISHOP. Elizabeth, Exchanging Hats: Paintings. New York: Farrar, Straus and Giroux, 1996.

FERLINGHETTI, Lawrence, Who Are We Now. New York: New Directions Publishing Corporation, 1976. , The Wild Dreams of a New Beginning. New York: New Directions, 1988.

FRIEDMAN, Donald, The Writer's Brush : Paintings, Drawings, and Sculpture by Writers. Minneapolis : Mid-List Press, 2007.

JAMES, Henry, The Portrait of a Lady, Preface, New York : Scribner, 1908.

VONNEGUT, Kurt, Breakfast of Champions. New York : Delacorte Press, 1973.

WALCOTT, Derek. Tiepolo's Hound. New York: Farrar, Straus and Giroux, 2000. 